Journal of Social Sciences 2 (3): 68-73, 2006

ISSN 1549-3652

(C) 2006 Science Publications

\title{
Entrepreneurships Barriers of Pond Fish Culture in Bangladesh- A Case Study from Mymensingh District
}

\author{
${ }^{1}$ Md. Asaduzzaman Sarker, ${ }^{2}$ Ataharul Huq Chowdhury and ${ }^{3}$ Yoshihito Itohara \\ ${ }^{1}$ Graduate School of Agriculture, Yamaguchi University \\ ${ }^{2}$ Wageningen University \\ ${ }^{3}$ Professor, Faculty of Agriculture, Yamaguchi University, Japan
}

\begin{abstract}
The main purpose of the study was to identify the major barriers of pond fish culture entrepreneurships in Bangladesh. The population of the study consisted of all 285 fish farmers of the selected villages of Muktagacha upazila (sub-district) of Mymensingh district. Needed data were collected with questionnaire by personal interviewing of the respondents. Result shows that lack of technical knowledge on pond management, unavailability of credit and poor extension service and lack of information has been identified as the potential barriers of pond fish culture entrepreneurships. Findings also shows that education, income from pond fish culture, availability of information sources and knowledge on pond fish culture have negative significant relationships and age and family size have positive significant relationships with the barriers of pond fish culture entrepreneurships. However, the results of stepwise multiple regression indicates that $65.4 \%$ (Adjusted $R^{2}=0.654$ ) of the variance in the barriers of pond fish culture entrepreneurships could be explained by the explanatory variables of the study. This indicates that there are other variables working behind the barriers of pond fish culture entrepreneurships. Further stepwise multiple regression shows that barriers along with other factors (pond size, training received by the respondents and education) has significant influence on income from pond fish culture.
\end{abstract}

Key words: Barriers, entrepreneurships, pond fish culture

\section{INTRODUCTION}

The fishery sector though small, but is very important in the economy of Bangladesh. This sector contributes $4.86 \%$ of the GDP ${ }^{[1]}$. About $12.05 \%$ of the population depends directly, or indirectly, on fishing and ancillary occupations. The fishery sub-sector provides full-time employment to over 1.2 million people, which constitute about 3\% of the active population ${ }^{[2]}$. Another 11 million people indirectly earn their livelihood from activities related to fisheries (FFYP, 1998 $)^{[6]}$. The economic growth of fisheries sector is $3.65 \%$. Total production of fish was 2.22 million ton in the year 2005 of which $40 \%$ was produced from closed water fisheries (i.e. pond, baor 'ox-bow Lake' and shrimp farm). There are around 0.24 million ha pond in Bangladesh which is around 63\% of the total closed water fisheries ${ }^{[1]}$. Due to increasing demand of fish for the growing population of Bangladesh, pond fish culture becoming popular to the farmers of rural Bangladesh. Production of pond fish culture has also been doubled in last decade ${ }^{[1]}$. Considering economic profitability of pond fish culture in comparison to cultivating rice or any other crops, farmers of Mymensingh district is converting their rice fields into pond. Now a day's pond fish culture has become a popular enterprise to the farmers in the study area. But still this entrepreneurship has some potential barriers which are working behind the growth and development of pond fish culture in Bangladesh. Without identifying and eliminating those barriers it is difficult to attain the satisfactory growth of this entrepreneurship. Thus, the authors took the research with the purpose of identifying the pond fish culture's entrepreneurships barriers and their seriousness to the farmers. The specific objectives of the study were:

* To identify and explain the potential barriers of pond fish culture entrepreneurships;

* To determine and describe the selected attributes of the fish farmers in rural Bangladesh;

* To assess the relationships between the selected attributes of the fish farmers and barriers faced by them in pond fish culture;

* To determine how much of the variance in the barriers of pond fish culture entrepreneurships could be explained by the explanatory variables of the study; and

* To determine the influence of pond fish culture barriers and other factors on income from pond fish culture.

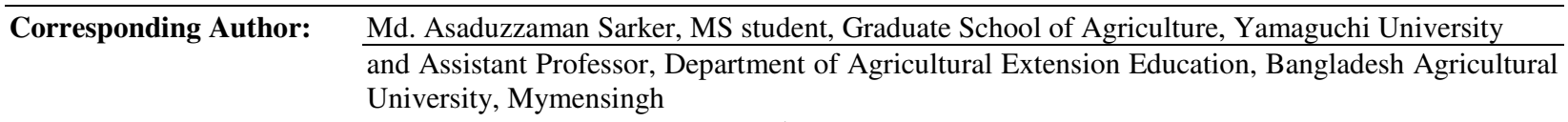




\section{MATERIALS AND METHODS}

Empirical data were collected from two villages namely Malotipur and Kumargatha of Muktagacha upazila (sub-district) under Mymensingh district by personal interviewing. A list of 285 fish farmers of the selected villages were prepared with consultation of the officials of upazila Fisheries Office that was treated as the population of the study. A representative sample of 90 fish farmers were taken as sample of the study. A Focus Group Discussion (FGD) was arranged to identify the potential entrepreneurships barriers of pond fish culture. Fish farmers, Upazila Fisheries Officer (UFO) and other extension workers were present in the FGD. From the discussion of the FGD, twelve (12) important barriers were identified. These selected barriers were incorporated into the questionnaire for knowing their seriousness, as a barrier to the farmers regarding pond fish culture. Each of the selected barriers regarding pond fish culture entrepreneurship was measured by a 4-point rating scale with responses of high, medium, low and no and weights for each of these responses were 3,2,1 and 0 respectively. For clear understanding of the seriousness of a barrier to the farmers with respect to pond fish culture, a total barrier indices (TBI) was calculated with the following formula:

Total Barrier Indices $(\mathrm{TBI})=\left(\mathrm{N}_{\mathrm{no}} \mathrm{X} 0\right)+\left(\mathrm{N}_{\mathrm{lo}} \mathrm{X} 1\right)+$ $\left(\mathrm{N}_{\mathrm{me}} \mathrm{X} 2\right)+\left(\mathrm{N}_{\mathrm{hi}}\right.$ X 3)

Where,

$\mathrm{N}_{\mathrm{no}}=$ Number of fish farmers with no barrier

$\mathrm{N}_{\mathrm{lo}}=$ Number of fish farmers with low barrier

$\mathrm{N}_{\mathrm{me}}=$ Number of fish farmers with moderate barrier

$\mathrm{N}_{\text {hi }}=$ Number of fish farmers with high barrier

Total Barrier Indices (TBI) in respect of any selected barrier could range from 0 to 270 .

\section{RESULTS AND DISCUSSION}

Barriers of pond fish culture: Total barrier indices (TBI) of twelve barriers were presented in Table1. Data in the table shows that total barrier indices ranged from 81 to 204 against a possible range of 0 to 270 . Findings reveal that lack of technical knowledge on pond management hold the position the top position as a tough barrier and lack of government initiative for maintaining favorable entrepreneurship's atmosphere hold lowest position as a weak barrier of pond fish culture. A terse description of the twelve aspects of barriers has been presented below:

Lack of quality fish fry and fingerlings: Although fish fry can be produced in large quantities, both by the private sector and government hatcheries or fish seed multiplication farms the supply of fingerlings is increasingly a real constraint to expanded fish production in the country. Each year, more than 1,000 million fish seeds are required. At present, only an estimated 500 million $2.5-5.0 \mathrm{~cm}$ fingerlings are produced from all the different sources - wild and artificial (hatchery-produced). There is thus a $50 \%$ or 500 million shortfall in demand of 1,000 million seeds. Most of the fish farmers (67.77\%) have mentioned 'lack of quality fish fry and fingerlings' as a major barrier of pond fish culture entrepreneurships.

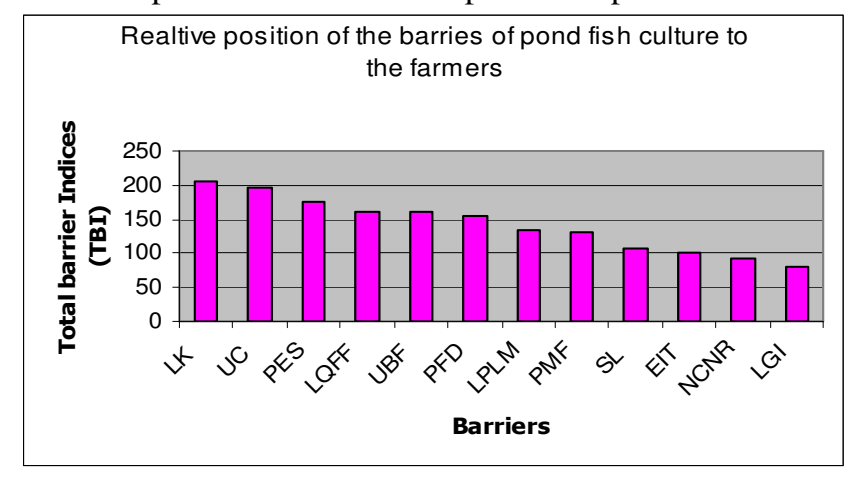

Fig. 1: The rank order of the selected barriers of pond fish culture

$\begin{array}{ll}\text { Legend: } & \\ \text { LK- } & \text { Lack of knowledge on pond management } \\ \text { UC- } & \text { Unavailability of credit } \\ \text { PES- } & \text { Poor Extension Services and Lack of Information } \\ \text { LQFF- } & \text { Lack of quality fish fry and fingerlings } \\ \text { UBF- } & \text { Unavailability of balanced feed material } \\ \text { PFD- } & \text { Prevalence of fish diseases } \\ \text { LPLM- } & \text { Low prices of fish in local markets } \\ \text { PMF- } & \text { Poor market facilities } \\ \text { SL- } & \text { Shortage of labor in time of need } \\ \text { EIT- } & \text { Effect of increased terrorism } \\ \text { NCNR- } & \text { Non cooperation from neighbors (fish theft and pouring } \\ & \text { poison in the pond) } \\ \text { LGI- } & \text { Lack of govt. initiative for maintaining favorable } \\ & \text { entrepreneurships atmosphere }\end{array}$

Poor extension service and lack of information: The overwhelming majority $(81.11 \%)$ of the fish farmers mentioned that they have to face either medium or high level barrier of poor extension service and lack of information. Farmers don't get necessary and useful information and advice from the extension agents (both GOs and NGOs). The number of field extension workers is very limited in public sector extension service. On the contrary, number of extension agents under NGO sector is sufficient but they don't have proper technical education. Besides, NGO's extension agents only provide extension service to their target farmers. Among the identified barriers it ranked $3^{\text {rd }}$ position (Fig. 1).

Unavailability of credit: For running an enterprise capital is the prime factor. When farmers don't have sufficient capital they have to search for credit to continue his or her entrepreneurship. In Bangladesh, the credit situation of the public sector for pond fish farmers is very poor. It was reported that only $20 \%$ of fish farmers in the country obtained institutional credit $^{[3]} . \mathrm{Alam}^{[4]}$ on the other hand, reported that about $16 \%$ of pond farmers could obtain credit from either 
public or private sources. But access of all fish farmers is not equal to all of three credit sources. For getting loan from commercial banks, it is mandatory to mortgage land or any resources. That's why only wealthier farmers can get the chance of getting credit facilities of commercial banks. Besides, the way of Table 1: Barriers faced by the fish farmers

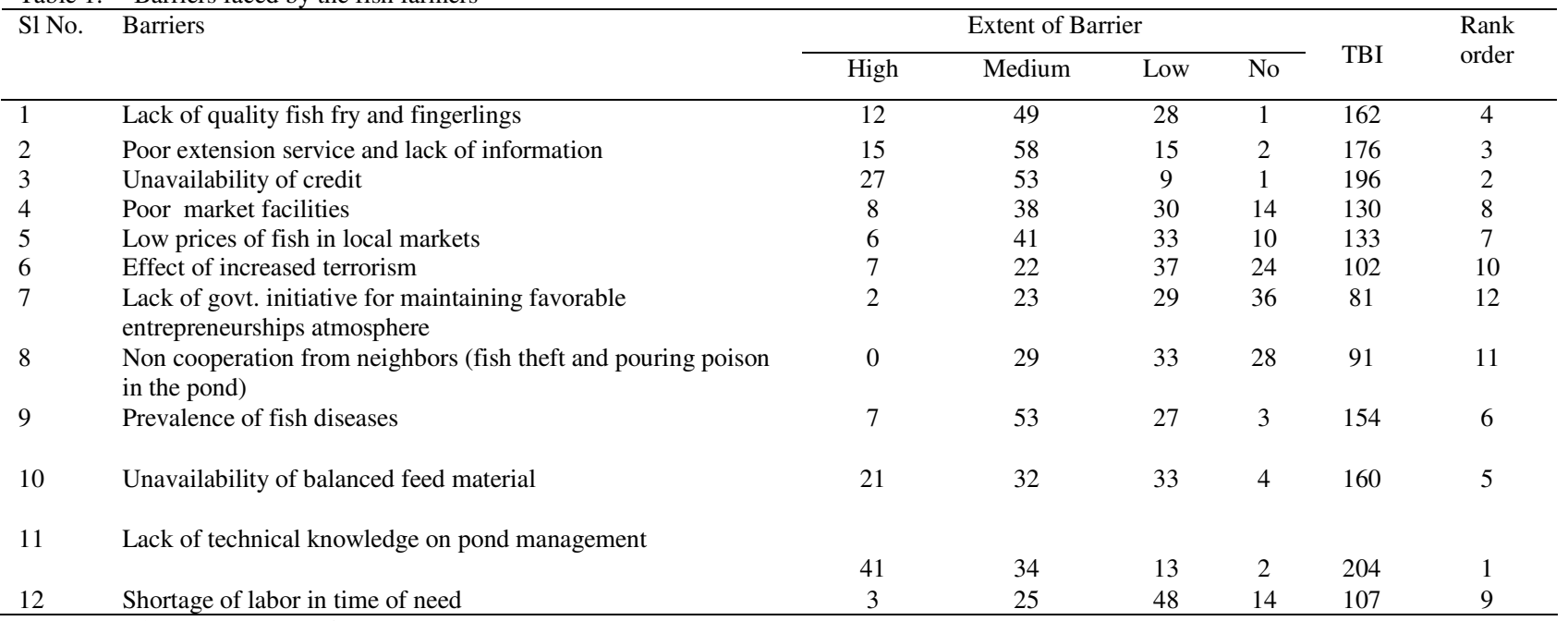

getting credit from commercial banks is also complicated. Farmers have to depend on brokers and have to offer them bribes for getting credit some times. On the other hands NGOs provide credit usually to land

Source: Authors' survey (2005)

Table 2: Descriptive statistics of the selected attributes of the fish farmers $(\mathrm{N}=90)$

\begin{tabular}{|c|c|c|c|c|c|}
\hline \multirow[t]{2}{*}{ Attributes } & \multirow[t]{2}{*}{ Scoring method } & \multicolumn{2}{|c|}{ Observed score } & \multirow[t]{2}{*}{ Mean } & \multirow{2}{*}{$\begin{array}{l}\text { Standard } \\
\text { Deviation }\end{array}$} \\
\hline & & Minimum & Maximum & & \\
\hline Age & Number of years & 20 & 80 & 39.41 & 11.42 \\
\hline Gender & Dummy & 0 & 1 & 0.79 & 0.41 \\
\hline Education & Scale score & 0 & 4 & 1.7 & 1.003 \\
\hline Family size & Number of family members & 2 & 14 & 6.64 & 2.45 \\
\hline Extent of family cooperation & Scale score & 0 & 13 & 5.29 & 2.41 \\
\hline Pond size & In hectares & 0.12 & 9.0 & 1.39 & 1.44 \\
\hline $\begin{array}{l}\text { Availability of information } \\
\text { sources }\end{array}$ & Scale score & 6 & 28 & 11.94 & 4.54 \\
\hline $\begin{array}{l}\text { Training received on pond fish } \\
\text { culture }\end{array}$ & Dummy & 0 & 1 & 0.47 & 0.5 \\
\hline Knowledge on pond fish culture & Knowledge test score & 7 & 24 & 14.99 & 4.62 \\
\hline
\end{tabular}

Source: Results of authors' analysis (2006)

less, marginal and small farmers and interest rate of NGOs loan is also very high. Besides, farmers fail to get credit form these above mentioned sources in time of need, so they have to collect credit from Mohazon (Financier or moneylender) with very high interest rate. TBI 196 indicates that unavailability of credit is a major barrier of pond fish culture entrepreneurships and ranked $2^{\text {nd }}$ position (Fig. 1).

Poor market facilities: The overall marketing facility in rural Bangladesh is really very poor. A big portion $(42 \%)$ of the farmers mentioned 'poor marketing facilities' as a medium level barrier of pond fish culture. The fish market at the primary catch stage is very non-competitive. As a result, exploitation by intermediaries, particularly wholesalers/Aratdars, is high in the secondary and higher secondary markets, which resemble oligopoly-type markets. Hence, fishing communities remain poor. Fifty-five $\%$ of fish vendors sell fresh fish in rural primary markets, $17 \%$ deal in live fish, and dry fish sellers constitute $7 \%$ of all vendors dealing in fish ${ }^{[4]}$. The broadly used fish market channel (product distribution route) is: Fisherman, Bepari/Chalani, Aratdar (Commission agent in landing centre), Paiker/retailer and consumer.

Low prices of fish in local markets: Due to poor transportation system in the rural Bangladesh, farmers mostly sell their harvested fish in the local markets. But purchasing capacity of the consumers in the local market is not so strong. Besides, farmers don't have own chilling system for preserving harvested fishes so most of the time farmers have to sell their harvested fishes in low prices immediate after harvesting. Prices of fish are determined by demand for and supply of fish quantities in the retail markets. The usual practice for pricing fish is still bargaining based on visual estimations. However, about half (45\%) of 
the farmers opined that it is a medium level barrier to them

Effect of increased terrorism: Due to increase of terrorism in the recent times all types entrepreneurs are facing lack of safety in Bangladesh. This situation is prevailing from capital city to remote villages. Terrorists always demand different amount of money to the farmers. If farmers fail to give the terrorist the demanded amount they harassed by the terrorist in various ways. Sometimes terrorist pour insecticides, sometimes they catch fishes. But in the study less than half $(41 \%)$ of the fish farmers mentioned it as a low level barrier for pond fish culture.

Lack of government initiative for maintaining favorable entrepreneurship's atmosphere: Government has an important role to maintain the favorable entrepreneurships atmosphere for all types of entrepreneurships. Respondent farmers mentioned that it is not so strong barrier for pond fish culture entrepreneurships.

Non cooperation from neighbors (fish theft and pouring poison in the pond): Village politics is very badly practiced in rural Bangladesh. Conflict between families is very common. Sometimes these conflicts motivate neighboring farmers to do harm to others. They sometimes steal fishes form ponds or pour poison to damage fishes from jealousness. Though one-third (31\%) of the farmers mentioned it as non barriers but about $37 \%$ farmers opined it as a low level barrier for pond fish culture entrepreneurships.

Prevalence of fish diseases: Prevalence of fish diseases is considered as one of the major reasons of poor fish production in Bangladesh. Faruk et.al. ${ }^{[5]}$ reported that approximately $15 \%$ income loss occurred due to fish diseases. Findings reveal that tow third of the fish farmers reported prevalence of diseases of fish diseases as medium to high level barrier for pond fish culture. Most of the rural fish farmers don't have sufficient knowledge on fish disease management. Even they do not understand the signs of diseases and can not report properly about the incidence to Upazila Fisheries Officer (UFO). As a result farmers are facing this barrier hardly.

Unavailability of balanced feed material: For profitable fish production supply of balanced feed materials to the pond is very much essential. But more than half of the framers mentioned 'unavailability of balanced feed materials' as an important barrier of pond fish culture. Majority of them use only urea fertilizers, cow dung and rice barn in their pond. But due to reduce of number of cattle in the in the farm families rate of using cow dung in the pond has also been reduced. Though ready fish feed (pellet) is now available in the market in small scale but its supply is insufficient and price is also very high and beyond the purchasing limit of small and marginal fish farmers. Thus still balanced feed material is an important barrier to the farmers.

Lack of technical knowledge on pond management: Proper technical knowledge is the most important thing for managing the sensitive entrepreneurship like pond fish culture. Farmers, who intend to continue pond fish culture, should have good technical knowledge on different aspects of it; otherwise they can not make their business profitable. A high TBI of 204 indicates

Table 3: Correlation between barriers of pond fish culture entrepreneurships and fish farmers' personal characteristics

\begin{tabular}{lc}
\hline Selected attributes of the farmers & $\begin{array}{l}\text { Correlation co-efficient (r) with } \\
\text { barriers of pond fish culture } \\
\text { entrepreneurships }\end{array}$ \\
\hline Age & $0.392^{* *}$ \\
Education & $-0.598^{* *}$ \\
Family size & $0.218^{*}$ \\
Extent of family cooperation & 0.026 \\
Pond size & -0.083 \\
Income from fish culture & $-0.277^{* *}$ \\
Availability of information sources & $-0.612^{* *}$ \\
Knowledge on fish culture & $-0.529^{* *}$ \\
\hline
\end{tabular}

** $\mathrm{p}<0.01 ; * \mathrm{p}<0.05$

Source: Results of authors' analysis (2006)

that pond fish farmers' perceived lack of knowledge on modern pond management was the major barrier of pond fish culture entrepreneurships .Majority (45.55\%) of the farmers mentioned that they felt lack of knowledge on modern pond management as high level barrier of this entrepreneurships. As about $44 \%$ of the fish farmers had no to primary level of education and due to poor extension service and lack of information farmers has great scarcity of knowledge on modern pond management. Besides training facilities on pond management for the farmers is also very limited hence lack of knowledge on modern pond management seems to be a major barrier of pond fish culture and ranked as number one barrier (Fig. 1).

Shortage of labor in time of need: For smooth running of pond fish culture enterprise necessity of labor forces is unavoidable. Though majority (53\%) of the farmers mentioned it as a low level barrier but due to increasing trend of labor migration from agricultural sector to non farm sector fish entrepreneurs has to face great difficulties in time of labor needed.

Attributes of the farmers and their barriers faced in pond fish culture: With the purpose of determining the relationships between fish farmers' faced barriers in pond fish culture entrepreneurships their selected attributes were measured first. Table 2 demonstrates different selected attributes of the fish farmers.

Coefficient of correlation were computed to ascertain the relationships between the selected attributes of the fish farmers and their faced barriers in 
pond fish culture entrepreneurship, which is presented in Table 3.Findings reveal that education, income from fish culture, availability of information sources and knowledge on pond fish culture have significant negative relationships with their barriers faced by the farmers in pond fish culture.
On the other hand age and family size have positive significant relationship with barriers faced by the farmers in pond fish culture where as extent of family cooperation and pond size don't have any significant relationships with barriers faced by the farmers. A negative relationship between barriers faced

Table 4: Results of the step wise multiple regression analysis showing contribution of the selected independent variables on barriers of pond fish culture entrepreneurships

\begin{tabular}{|c|c|c|c|c|c|}
\hline Model & Combination of explanatory variables & $\begin{array}{c}\text { Co-efficient of determination } \\
\qquad\left(R^{2}\right)\end{array}$ & Adjusted $R^{2}$ & $\begin{array}{c}\% \text { increase in adjusted } \\
R^{2}\end{array}$ & $F$-value \\
\hline 1 & Constant + Training received by the farmers & 0.410 & 0.403 & 40.3 & $61.109 * *$ \\
\hline 2 & Constant + Training received by the farmers + & & & & \\
\hline & Availability of information sources & 0.552 & 0.542 & 13.9 & $53.691 * *$ \\
\hline 3 & $\begin{array}{c}\text { Constant }+ \text { Training received by the farmers+ } \\
\text { Availability of information sources + Income from } \\
\text { pond fish culture }\end{array}$ & 0.599 & 0.585 & 4.3 & $42.804 * *$ \\
\hline & $\begin{array}{l}\text { Constant }+ \text { Training received by the farmers }+ \\
\text { Availability of information sources }+ \text { Income from } \\
\text { pond fish culture }+ \text { Pond size of the respondents }\end{array}$ & 0.645 & 0.628 & 4.3 & $38.619 * *$ \\
\hline 5 & $\begin{array}{c}\text { Constant }+ \text { Training received by the farmers+ } \\
\text { Availability of information sources }+ \text { Income from } \\
\text { pond fish culture }+ \text { Pond size of the respondents }+ \\
\text { Knowledge on pond fish culture }\end{array}$ & 0.673 & 0.654 & 2.6 & $34.625 * *$ \\
\hline
\end{tabular}

Source: Results of authors' analysis (2006)

Table 5: Results of the step wise multiple regression analysis showing influence of the barriers and other factors on income from pond fish

\begin{tabular}{|c|c|c|c|c|c|}
\hline Model & Combination of explanatory variables & $\begin{array}{l}\text { Co-efficient of determination } \\
\qquad\left(R^{2}\right)\end{array}$ & Adjusted $R^{2}$ & $\begin{array}{c}\text { \% increase in adjusted } \\
R^{2}\end{array}$ & $F$-value \\
\hline 1 & Constant + Pond size of the respondent & 0.616 & 0.612 & 61.2 & $37.396 * *$ \\
\hline 2 & $\begin{array}{l}\text { Constant }+ \text { Pond size of the respondent }+ \text { Barriers } \\
\text { of pond fish culture }\end{array}$ & 0.661 & 0.654 & 4.2 & $35.325 * *$ \\
\hline & $\begin{array}{c}\text { Constant }+ \text { Pond size of the respondent }+ \text { Barriers } \\
\text { of pond fish culture }\end{array}$ & 0.686 & 0.675 & 2.1 & $34.225 * *$ \\
\hline 4 & $\begin{array}{c}\text { Constant }+ \text { Pond size of the respondent }+ \text { Barriers } \\
\text { of pond fish culture }\end{array}$ & 0.702 & 0.688 & 1.3 & $33.504 * *$ \\
\hline
\end{tabular}

Source: Results of authors' analysis (2006)

by the farmers and education indicates that farmers having more education less they face barriers in pond fish culture. Farmers having more education are more competent and capable to manage an enterprise smoothly. Thus barriers are limited to the higher educated farmers than less educated and non-educated farmers.

A negative relationship between income from fish culture and barriers indicate that farmers having low income have high barriers than those have high income. Farmers belongs to high income group can minimize few of their barriers with their higher income. They can easily collect quality of fish fry and fingerlings, balanced feed materials even from distance town that is really absurd to low income farmers. Even high income farmers can hire specialist consultant foe his fish farm. A negative relationship between availability of information sources and barriers faced by them indicates that the more available information to the farmers the less they face barriers. Similarly, negative relation between barriers with knowledge on pond fish culture indicate that if concern agencies can improve knowledge of the farmers through the process of training and other extension methods can reduce the barriers of the farmers' remarkably.
A positive relationship between barriers and age of the farmers indicates that farmers having the more age have higher the barriers on pond fish culture than young farmers. As young farmers are more dynamic and cosmopolite, they can easily collect essential technical information and can consult with Upazila Fisheries Officer (UFO) and other extension personnel in any difficult situation so their barriers are also less than the old fish farmers. Similarly, a positive relationship between barriers and family size indicates that farmers having the large family size have higher the barriers on pond fish culture.

Factors responsible for the entrepreneurships barriers of pond fish culture: Stepwise multiple regression analysis (Table 4) shows that out of eleven (11) explanatory variables only five variables finally entered in the model and combination together of these variables contributed $65.4 \%$ of the total variance in respect of entrepreneurship's barriers of pond fish culture. The significant contribution was made by training received by the farmers on fish culture, availability of information sources, income from pond fish culture, pond size of the respondents and knowledge of the farmers on fish culture. It is 
interesting to note that all the significant variables shows negative relationship with barriers of pond fish culture entrepreneurships. However, training received by the farmers on pond fish culture solely contributes highest $(40.3 \%)$ to explain the barriers of pond fish culture entrepreneurships.

It may be assumed from the result from the stepwise multiple regression analysis that trained farmers has more knowledge and skill for better pond management. Training on pond fish culture can make them potential and successful entrepreneurs thus more training programme should be arranged for the fish farmers for better growth and development of this sector. Framer would overcome many of their barriers if they get necessary technical information in time. So, special attention should be given to strengthen extension services in fisheries sector unlike crop sector for assuring sufficient flow of information as well as to improve the knowledge and skill of the fish farmers through training and other extension teaching methods.

Influence of barriers and other factors on income from pond fish culture: The main purpose of any enterprise is to earn more. But, due interference of known barriers and unknown factors entrepreneurs sometimes fail to earn expected amount from his or her enterprise. Table 5 shows the influence of the known barriers and other associated factors on income from pond fish culture.

Stepwise multiple regression analysis (Table 5) shows that barriers along with other associated factors have $68.8 \%$ influences on income from pond fish culture. Among these factors pond size has highest contribution $(61.2 \%)$ and selected barriers of pond fish culture has $4.2 \%$ influences on income from pond fish culture. The other influential factors are training and educational level of the farmers. Table 4 also shows that training has also significant influence on barriers of pond fish culture.

\section{CONCLUSION}

The case study on pond fish culture entrepreneurships revealed the following. Firstly, pond fish culture entrepreneurship's has some potential barriers like lack of technical knowledge on pond management, unavailability of credit and poor extension service and lack of information, and lack of quality fish fry and fingerlings. There are some moderate and few weak barriers also. Secondly, some selected attributes of the fish farmers has significant relationships with barriers faced by them.
Among these attributes education, income from pond fish culture, availability of information sources, and knowledge on pond fish culture have significant negative relationships and age and family size have significant positive relationships with barriers faced by the fish farmers. Thirdly, five factors (training received, availability of information sources and knowledge on pond fish culture) are responsible for highest variation $(65.4 \%)$ in the barriers faced by the fish farmers incase of doing the business of pond fish culture. Probably, there are other important factors that are also responsible for creating barriers in pond fish culture entrepreneurships. Further research is needed to identify those factors. Fourthly, barriers of pond fish culture significantly (4.2\%) influenced income from fish culture. So it can be concluded that if the concern policy makers take careful initiative to minimize the barriers and factors behind it, pond fish culture may become a highly profitable enterprise in Bangladesh and can contribute significantly in national economy.

\section{REFERENCES}

1. Bangladesh Economic Review, 2006. Economics Division, Ministry of Finance. Government of the Peoples' Republic of Bangladesh..

2. BBS, 1996 . Statistical Yearbook of Bangladesh 1996. Statistics Division, Ministry of Planning, Govt. of the Peoples' Republic of Bangladesh.

3. Shang, Y.C., 1990. Socio-economic constraints of aquaculture in Asia. World Aquacult., 21: 34-43.

4. Alam, S., 2000. Production, accessibility and consumption patterns of aquaculture products in Bangladesh. Report submitted to ICLARM, Penang, Malaysia.

5. Faruk, M.A.R., M.M.R. Sarker, M.J. Alam and M.B. Kabir, 2004. Economic loss from fish diseases on rural freshwater aquaculture of Bangladesh. Pak. J. Biol. Sci., 7: 2086-2091.

6. FFYP, 1999. Fifth Five Years Planning, Planning Division, Ministry of Planning, Government of the Peoples' Republic of Bangladesh. 